\title{
A reappraisal of the stratigraphy and depositional development of the Upper Greensand (Late Albian) of the Devizes district, southern England
}

UPPER GREENSAND STRATIGRAPHY, DEVIZES, WILTSHIRE, UK

M. A. Woods ${ }^{1}$, I. P. Wilkinson ${ }^{1}$, G. K. Lott ${ }^{1}$, K. A. Booth ${ }^{1}$, A. R. Farrant ${ }^{1}$, P. M. Hopson $^{1}$ and A. J. Newell ${ }^{2}$

Woods, M. A., Wilkinson, I. P., Lott, G. K., Booth, K. A., Farrant, A. R., Hopson, P. M. \& A. J. Newell. 200\#. A reappraisal of the stratigraphy and depositional development of the Upper Greensand (Late Albian) of the Devizes District, southern England. Proceedings of the Geologists’ Association, XXX. 000 - 000. Three members are recognised within the Upper Greensand Formation of the Devizes district on the basis of outcrop, newly acquired cored borehole and petrographical data. These are, in ascending stratigraphical order, Cann Sand Member, Potterne Sandstone Member and Easterton Sandstone Member. Compared to the imprecise historical subdivisions, the members provide a much clearer indication of lithological variation through the Upper Greensand, and this in turn provides clues to its depositional development. The biostratigraphy of each member has been determined using macrofossils and microfossils. The new biostratigraphical data clarifies the relationship of the Potterne Rock to the traditionally named 'Ragstone' which caps the Shaftesbury Sandstone in the Shaftesbury district, and suggests that the correlation of the Potterne Rock and 'Ragstone' is less straightforward than previously suggested. 
There are some distinct contrasts with the stratigraphy of the Upper Greensand southwest of Devizes (Shaftesbury \& Wincanton districts). Whilst tectonic influences have been demonstrated to affect coeval strata in parts of the eastern Weald, these may not be the dominant control on the Devizes succession, which seems to be more strongly influenced by its palaeogeographical setting with respect to sediment source areas, and the effect this had on the volume and timing of sediment infill. Palaeogeography may also be indirectly responsible for the absence of cherts in the Upper Greensand of the Devizes area, in contrast to their conspicuous development in the Upper Greensand of southwest England and the Weald.

Key words: Albian, Upper Greensand, Lithostratigraphy, Biostratigraphy, Wiltshire

${ }^{1}$ British Geological Survey, Keyworth, Nottingham NG12 5GG, UK (e-mail: maw@bgs.ac.uk)

${ }^{2}$ British Geological Survey, Maclean Building, Crowmarsh Gifford, Wallingford, Oxon OX10 8BB

\section{INTRODUCTION}

The Upper Greensand of the Devizes district is famed for its abundant fossils, with several significant collections amassed in the latter part of the 19th century now residing in major British museums. It was Jukes-Browne’s (1892) work in the Devizes area that established our current understanding of the Gault and Upper Greensand formations as contemporaneous deposits (now unified in the Selborne Group of Hopson et al., 2008). However, relatively little has been published on the 
succession since this work (Jukes-Browne, 1892, 1905; Jukes-Browne \& Hill, 1900) more than a century ago. Thus, the new geological survey of the Devizes district (1:50 000 geological sheet 282), commenced by the British Geological Survey (BGS) in 2004 and completed in Spring 2005, presented an opportunity to re-evaluate the earlier work in the context of modern stratigraphy. Although the combined effects of landslipping and poorly and impersistently developed topographical features prevented member subdivisions from being defined on the new geological map, the data from sections and cored boreholes (Fig. 1) did provide ample evidence of stratigraphical changes that could be used to correlate between successions locally and further afield. These observations form the basis for a revised subdivision of the Devizes Upper Greensand, supported by macrofossil, microfossil and thin-section data. Significantly, the current work has identified the Potterne Rock of Jukes-Browne \& Hill (1900) as a well-developed marker-bed at several localities, and provides the first description of this horizon in more than 100 years.

The stratigraphy of the Upper Greensand of the Devizes district is summarised on Figure 2. The Late Albian biozonal scheme used in this work follows Owen (1975, 1984), but the relationship to the recently revised scheme of Owen \& Mutterlose (2006) is shown on Figure 3. Modern interpretations of outdated species names and obsolete zonal nomenclature are given in square brackets in the text. The specimens cited herein belong to the BGS Collections at Keyworth, Nottingham. 


\section{PREVIOUS RESEARCH}

The most detailed historical accounts of the Upper Greensand of the Devizes district were made in the late 19th and early 20th centuries by Jukes-Browne $(1892,1905)$ and Jukes-Browne \& Hill (1900). The historical nomenclature for the succession is confusing and explained below (Fig. 2).

The earliest account of the district (Jukes-Browne, 1892) appears to describe two broad subdivisions of the Upper Greensand, comprising 'Malmstone' overlain by 'Grey and green sands'. 'Malmstone' consisted of grey or buff sandstone with common sponge spicules and globules of silica derived from the spicules, and a macrofauna dominated by the small, partly coiled annelid Rotularia. However, Malmstone only accounted for the lower part of the succession found beneath the 'Grey and green sands'; the higher part was soft, micaceous and glauconitic sandstone, with an abundant and diverse macrofauna, capped by a bed of calcareous sandstone, named Potterne Rock. The interval from the base of the Malmstone to the Potterne Rock was stated to be about $21 \mathrm{~m}$ thick, and a similar thickness was assigned to the 'grey and green sands' near Devizes, although this unit apparently thins to little more than a metre a few kilometres north of Devizes. The 'Grey and green sands' contained beds of 'hard greenish rock', had a macrofauna dominated by pectinid bivalves (especially Pecten asper Lamarck [Merklinia aspera (Lamarck)]), and lacked chert (in contrast to coeval strata seen further south near Warminster).

In a later account (Jukes-Browne \& Hill, 1900, p. 249-265), the Upper Greensand succession is described initially in terms of 'Malmstone', micaceous sandstone and 
fine, grey sands capped by Potterne Rock (24 to 27 m thick) overlain by 'Greensands' (18 - 21 m thick). Jukes-Browne \& Hill (1900), following Barrois (1876), used the term 'Gaize' for the distinctly micaceous strata seen below the 'grey and green sands'. Subsequently the name 'Devizes Beds' was used by Jukes-Browne \& Hill (1900, p. 252) for the interval from the base of the Upper Greensand to an horizon of a pale sandstone speckled with green glauconite ('speckled sandstone') about $10 \mathrm{~m}$ above the Potterne Rock. The succession above the 'speckled sandstone' was described as the 'Zone of Pecten asper and Cardiaster fossarius'. Thus, the key difference with the earlier account of Jukes-Browne (1892) is that the relative stratigraphical position of the two-fold subdivision of the Upper Greensand succession has shifted upwards from the Potterne Rock to the 'speckled sandstone' (Jukes-Browne \& Hill,1900, p. 251).

In the final comprehensive description of the Devizes succession (Jukes-Browne, 1905), the subdivision of the Upper Greensand is essentially that previously described by Jukes-Browne (1892), but with some modification of terminology. 'Malmstone' is clearly distinguished from the micaceous and fossil-rich sandstone higher in the succession, which Jukes-Browne also refers to as 'Gaize'. The 'Malmstone' and 'Gaize' are grouped as the 'Middle' of the three subdivisions of the Selbornian Formation (a term introduced by Jukes-Browne \& Hill (1900) and equivalent to the combined Gault and Upper Greensand); the 'Lower' subdivision is represented by the Gault and the 'Upper' subdivision equates with the 'grey and green sands' of Jukes-Browne (1892).

More recent work on the Devizes succession is very limited. Spath (1923-1943) described many of the ammonites from the succession, and noted that much of it belonged to the C. auritus Subzone (Fig. 3). Drummond (1970) outlined the general 
Upper Greensand succession for the Devizes area, largely following Jukes-Browne (1905), except for the introduction of 'Devizes Sands' for the post-Potterne Rock succession. Drummond (1970) also emphasised that the Potterne Rock was likely to mark a significant regional event of restricted deposition, current winnowing and erosion across the Wessex Basin, and equated it with a range of distinct contemporaneous lithofacies in the Upper Greensand of southwest England. Kelly (1971) described c. 9 m of Upper Greensand in a now obscured roadside succession near Edington [ST 941 536], c. 9 km southwest of Devizes, which contained an auritus Subzone macrofauna. Owen (1975) provided some general information about the ammonite zonation of the Potterne Rock and underlying succession.

\section{LITHOSTRATIGRAPHY}

On the basis of 19 key outcrop successions and three new cored boreholes in the Devizes district (Fig. 1), this work divides the Upper Greensand Formation into three members. In ascending stratigraphical order these are: Cann Sand Member, Potterne Sandstone Member (new) and Easterton Sandstone Member (new) (Fig. 4). Each of these units is described in detail below, and for quick reference, summary definitions are given in Appendix A.

\section{Cann Sand Member}

The Cann Sand Member was defined by Bristow et al. (1989, 1995), and forms the oldest part of the Upper Greensand in the Wincanton and Shaftesbury districts, southwest of Devizes. In the Devizes area, the lower part of the member is poorly 
exposed in three sections at Furze Hill Farm [ST 98868 59993, ST 98857 59981, ST 98834 59950] near Devizes and further west near Coulston [ST 95339 53904], and was cored in the BGS Old Park Farm Borehole, near Devizes [ST 99476 60353], where the basal $7.86 \mathrm{~m}$ of the member occurs resting on Gault (Figs 1, 5, 6). The higher part of the member is well exposed in the vicinity of Devizes, especially either side of the Potterne Road (A360) leading south from Devizes [SU 0036060400 to SU $0024060060]$; in a section on the western outskirts of Devizes; south of the Kennet and Avon Canal [ST 99949 61536]; adjacent to a footpath on the northern outskirts of Devizes, north of the canal [ST 99860 61897]; in Peppercombe Lane, Urchfont [SU 0395 5738]; near Coulston; at Folly Wood, Easterton Sands [SU 0195 5683]; near Littleton Panell [SU 0025 5430] and adjacent to the bridleway near Stroud Hill Farm, near Potterne [SU 00681 58453] (Figs 1, 5). The 10.67 m deep Knights Leaze Farm Borehole [SU 03837 57419] is entirely in the higher part of the Cann Sand Member (Fig. 6). The sections at Furze Hill Farm suggest that the lower part of the member is about $10 \mathrm{~m}$ thick, with a further $11 \mathrm{~m}$ estimated for the upper part of the member at Potterne, giving a total thickness of $21 \mathrm{~m}$.

In the type area near Shaftesbury, the typical lithology of the Cann Sand is poorly consolidated, fine-grained, glauconitic, micaceous sand (Hopson et al., 2008). A broadly similar lithology, weathering pale to medium grey and orange-grey, occurs in the Devizes district, although the lower part is finer-grained, less micaceous and darker grey when unweathered compared to the upper part, and there are occasional horizons of phosphatic clasts and common bioturbation throughout. The base of the Cann Sand is marked by a sharp, slightly irregular surface at $7.86 \mathrm{~m}$ depth in the Old Park Farm Borehole, marking the upward facies change from silty mudstone of the 
Gault to muddy siltstones and sandstones. The upper part of the member contains rounded concretions and tabular horizons of more indurated, calcareously cemented sandstone (Fig. 7a); these appear to be more common than in the type area of the Cann Sand, although none seem to form a consistent horizon for correlation.

Thin sections of the Cann Sand from the Devizes district show that it comprises very fine-grained detrital quartz with subordinate feldspar, glauconite and muscovite mica in a micritic, muddy matrix. The extent of calcareous cementation is locally so great for the rock to be considered a limestone. Sponge spicules are an important part of the bioclastic component in thin-section that is not evident at outcrop, and are commonly leached, providing a source of secondary porosity. The lithology of the hard, concretionary horizons is very similar to that of the surrounding strata, but the cementation here comprises strongly ferroan spar carbonate rather than micrite.

In contrast to the type area, macrofossils are generally more abundant in the Cann Sand of the Devizes district, and indicate a significantly younger age for the top of the formation (Fig. 8). In the lower part of the member large specimens of Entolium orbiculare (J. Sowerby) and the annelid Rotularia are common, and occur with other bivalves such as Neithea quinquecostata (J. Sowerby) and Pinna robinaldina d'Orbigny. The ammonite Hysteroceras bucklandi? (Spath) was collected from a small exposure on the west side of the track [c. SU 00719 58423] near Stroud Hill Farm, Potterne, and Epihoplites? and Idiohamites turgidus? (J. Sowerby) were collected from the Furze Hill Farm sections. The ammonites suggest the H. varicosum or $C$. auritus subzones of the M. (M.) inflatum Zone for the lower part of the Cann Sand. The basal Cann Sand in the Old Park Farm Borehole contains the foraminifera 
Epistomina spinulifera (Reuss) and Hoeglundina carpenteri (Reuss), species normally typical of the D. cristatum Subzone but which are also reworked into the orbignyi and varicosum subzones (Price, 1977). The top of the underlying Gault in the Old Park Farm Borehole is probably of orbignyi or varicosum Subzone age based on the relative abundance of the foraminifera Arenobulimina chapmani Cushman and Citharinella pinnaeformis (Chapman) between $8.79 \mathrm{~m}$ and $10 \mathrm{~m}$ depth. Towards the top of this borehole, the concurrent ranges of Arenobulimina praefrankei and Haplophragmoides nonionoides angulosa Maginez-Jannin in the Cann Sand suggests assignment to the auritus Subzone.

The higher part of the Cann Sand has a much more abundant and diverse, bivalve and ammonite-dominated macrofauna. Bivalves include Callistina plana J. Sowerby, Entolium orbiculare, Modiolus flagellifera Forbes, Nannonavis carinata J. Sowerby, Neithea quinquecostata, Panopea mandibula J. Sowerby, Pinna robinaldina?, Pterotrigonia aliformis (Parkinson) and locally abundant oysters such as Pycnodonte (Phygraea) vesiculosum (J. Sowerby) and Amphidonte, with occasional Ceratostreon undata (J. de C. Sowerby). The ammonite fauna includes Anahoplites picteti Spath, A. planus (Mantell), Callihoplites auritus (J. Sowerby), C. aff. potternensis Spath, C. sp., Hysteroceras bucklandi? (Spath), Mortoniceras potternense? Spath and M. sp.; this assemblage is indicative of the C. auritus Subzone of the M. (M.) inflatum Zone.

The lower part of the Cann Sand Member broadly equates with the Malmstone of Jukes-Browne (1905). The historical record of Avicula gryphaeoides J. de C. Sowerby [Aucellina gryphaeoides (J. de C. Sowerby non Sedgwick)] in the Malmstone suggests that at least part of this interval is likely to belong to the C. auritus Subzone 
(Jukes-Browne \& Hill, 1900; Morter \& Wood, 1983). The lithology and fauna of the upper part of the Cann Sand corresponds well with Jukes-Browne \& Hill's (1900) description of 'fine micaceous sandstone' or 'Gaize' above the Malmstone, which Jukes-Browne (1905) estimated to be 30ft (c. 9 m) thick.

\section{Potterne Sandstone Member}

The Potterne Sandstone occurs in many of the sections previously described, including the sections at Folly Wood near Easterton Sands, Littleton Panell, along the A360 in Devizes, and the bridleway near Stroud Hill Farm [SU 00604 58448]. The best exposure is in Coxhill Lane, Potterne [SU 00125840 to SU 0062 5842], and there are further sections near Potterne [ST 99475 58308; SU 00110 58096], in Hartmoor Road, Devizes [SU 00056048 to ST 9993 6032], and in Friar Lane, Urchfont [SU 0426 5717] (Figs 1, 5). The member varies from 3.5 to 4 m thick in sections at Potterne, to about $1.7 \mathrm{~m}$ thick at Littleton Panell.

The Potterne Sandstone comprises distinctly soft, grey and greenish-grey weathering, moderately to poorly fossiliferous, glauconitic, fine- to very fine-grained sandstone with conspicuous burrows infilled with pale grey mudstone (Fig. 4). The unit is much less micaceous and significantly more glauconitic than the underlying Cann Sand. Small phosphatic nodules occur scattered through the greater part of the interval, which is capped by one or more beds of very hard, bioturbated and generally phosphate-bearing, fossiliferous glauconitic sandstone or sandy limestone. The base of the member is consistently marked at outcrop (e.g. Littleton Panell, Easterton Sands, Potterne, Devizes; Fig. 5) by the upward facies change from mica-rich 
sandstone of the Cann Sand, to fine-grained glauconitic sandstone without conspicuous mica.

In the section adjacent to the A360 in Devizes, a single, laterally persistent hard bed, $0.4 \mathrm{~m}$ thick, forms the top of the member, and is clearly equivalent to the 'Potterne Rock' as described at the same locality by Jukes-Browne \& Hill (1900, p. 254). A single horizon, of comparable thickness is also seen at Littleton Panell and at Folly Wood near Easterton Sands. However, in other sections, such as those seen at Friar Lane (Urchfont), Hartmoor Road (Devizes) and Potterne, the member is capped by a succession of up to three hard sandy limestones, occupying a total interval of $2.7 \mathrm{~m}$ at Potterne (Figs 5, 7b, c). In sections containing multiple hard beds it is not clear if only the highest unit is equivalent to the Potterne Rock seen in the section adjacent to the A360, or whether there is local expansion of the Potterne Rock interval to form several closely spaced indurated units.

Further west, in the road cutting south of Coulston and in an old pit at Westbury [ST 87368 50266], the Potterne Sandstone generally lacks scattered phosphatic clasts. A pair of cemented limestone beds occurs in the highest $3 \mathrm{~m}$ of both sections; the lowest is characterised by abundant serpulid remains and specimens of the brachiopod Cyclothyris cf. punfieldensis? Owen, and marks an upward facies change to poorly micaceous, fine-grained, glauconitic sandstone; the higher bed in the Coulston section was inferred to represent the Potterne Rock by Jukes-Browne (1905), and this is probably also true of the upper bed at Westbury based on the local presence of phosphatic clasts (Fig. 5). 
In thin-section, the succession below the Potterne Rock comprises weakly cemented glauconitic sandstone, with sporadic patches of muddy matrix. In contrast, the Potterne Rock is pervasively-cemented glauconitic sandstone, dominated by very fine- to fine-grained, detrital quartz with subordinate glauconite, sparse feldspar and bioclastic fragments, floating in a ferroan, spar-calcite cement.

Relatively few macrofossils have been found in the Potterne Member, and none are biozonally diagnostic. The most common fossils are oysters, such as Amphidonte obliquatum (Pulteney), Gryphaeostrea, Pycnodonte and Ceratostreon? undata, and a possible phosphatised Aucellina was seen at outcrop in a small landslipped exposure [SU 00110 58096] at Potterne. A microfossil sample from the Potterne Rock contained occasional plant fragments and the long ranging, Mid to Late Albian ostracod Mandocythere harrisiana.

Jukes-Browne \& Hill (1900, p. 251) recorded that the succession between the micaceous sandstone (presumed Cann Sand herein) and the Potterne Rock comprised soft, friable, fine-grained grey sands with large calcareous sandstone 'doggers' or 'burrstones'. However, in their description of the section adjacent to the A360, JukesBrowne \& Hill (1900, p. 254) only recorded 'burrstones' in the equivalent of the Cann Sand, the overlying succession, below the Potterne Rock, comprising 'soft, greenish grey sand containing more glauconite and less mica'. Near Easterton, Jukes-Browne (1905) recorded that the Potterne Rock contained phosphate nodules, and was underlain by c. 2 m of greenish-grey sand with common brown and black phosphate nodules in its upper part. This description clearly corresponds with the Potterne 
Sandstone. In the A360 section, Jukes-Browne \& Hill (1900) imply that the equivalent of the Potterne Sandstone is 4 feet (c. $1.2 \mathrm{~m})$ thick.

A former exposure of the Potterne Rock in a field north of Blount's Court Farm, Potterne, is the source of its famous C. auritus Subzone ammonite fauna, described by Spath (1923-1943). This is the only detail of Jukes-Browne \& Hill's (1900) description of the Potterne Rock that cannot be reconciled with recent observations, which showed the horizon to be rather poorly fossiliferous and lacking ammonites.

\section{Easterton Sandstone Member}

The Easterton Sandstone, comprising the remaining Upper Greensand succession between the top of the Potterne Rock and the base of the Chalk Group, has limited exposure in the Devizes district. About $3.8 \mathrm{~m}$ of the member are seen above the Potterne Rock in the section at Folly Wood, near Easterton, and just over $6 \mathrm{~m}$ occur in the section adjacent to the A360 south of Devizes. Limited exposures in the base of the member also occur above the Potterne Rock at Littleton Panell, Friar Lane, Urchfont, and Hartmoor Road (Devizes), and a temporary exposure around the middle of the member was seen near Etchilhampton [SU 05818 60407] (Figs 1, 5). The best record of the member is provided by the BGS cored borehole at Rookery Farm, Urchfont [SU 04010 56742], which proved 10.46 m of Easterton Sandstone below the base of the Chalk Group (Fig. 6). Jukes-Browne \& Hill (1900) recorded that equivalent strata were formerly well-exposed in the lanes between Lavington and Easterton. Although the succession is affected by landslipping, the Easterton 
Sandstone is thought to be about 20 m thick, based on field evidence, which is similar to the 60 feet (18 m) attributed to this interval by Jukes-Browne \& Hill (1900).

The Easterton Sandstone is a unit of strongly glauconitic, fine- to medium-grained sandstone, containing occasional beds of indurated, calcareous sandstone or sandy limestone (Fig. 7d). In the sections at Hartmoor Road (Devizes) and Littleton Panell, there are conspicuous clay-lined burrows (cf. Thalassinoides) in the basal part of the succession. Few burrows are developed in the very dark green, glauconitic sandstone seen at Etchilhampton, where there is a thin $(c .0 .1 \mathrm{~m})$ bed of hard, pale-coloured sandstone speckled with grains of dark glauconite, and a higher bed of hard, orangestained sandstone. In thin-section, the speckled bed is a siliciclastic and glauconitic, bioclastic limestone, dominated by moderately sorted, fine- to medium-grained, angular to sub-rounded quartz grains and glauconite, with subordinate feldspar, bioclasts and sparse mica in a pervasive ferroan spar carbonate cement. In the trackside leading to Urchfont Hill, the highest $1.3 \mathrm{~m}$ of the member comprises soft, bright green to greenish-grey glauconitic sandstone containing clay-lined burrows and a thin hard bed of glauconitic sandstone with a distinctly hackly fracture. In thinsection, this hard bed is another siliciclastic and glauconitic, bioclastic limestone. Overall the Easterton Sandstone is more glauconitic and coarser-grained than the Potterne Sandstone.

Very few macrofossils have been collected from the Easterton Sandstone. The best fauna, from spoil of the speckled sandstone bed seen at Etchilhampton (above), includes several specimens of Aucellina gryphaeoides with Entolium orbiculare and Neithea quinquecostata. The fauna is undiagnostic, but is not inconsistent with 
assignment to the $S$. dispar Zone, in which Aucellina is much more abundant than the underlying auritus Subzone (Morter \& Wood, 1983). Aucellina?, Neithea gibbosa? (Pulteney), Entolium orbiculare and Pycnodonte vesiculare were recovered from various levels in the cored succession in the Rookery Farm Borehole. At $11 \mathrm{~m}$ depth in this borehole there is tentative foraminiferal evidence for the S. dispar Zone based on the record of Arenobulimina barnardi Frieg \& Price and A. chapmani. JukesBrowne \& Hill (1900) noted few fossils from this part of the succession, apart from locally common Pecten asper [Merklinia aspera] in strata equivalent to the higher part of the Easterton Sandstone.

According to Jukes-Browne \& Hill (1900), the succession between the Potterne Rock and top of the Upper Greensand Formation comprises glauconitic sand without mica, containing horizons of calcareous sandstone. One of these sandstones, at about the middle of this interval, was a distinctive pale bed with dark specks of glauconite, at and above which Merklinia aspera was found. The description clearly matches that of the Easterton Sandstone, and the pale, 'speckled' sandstone might be that seen in the temporary excavation at Etchilhampton.

\section{CORRELATION}

The Upper Greensand Formation was divided into four members by Bristow (1989), comprising (in ascending stratigraphical order): Cann Sand, Shaftesbury Sandstone, Boyne Hollow Chert and Melbury Sandstone. The last named is Cenomanian in age, and is now regarded as part of the Chalk Group (Hopson, 2005). The Cann Sand, Shaftesbury Sandstone and Boyne Hollow Chert occur in the adjoining Wincanton 
and Salisbury districts, and also in the more distant Shaftesbury district (Bristow et al., 1995, 1999; Hopson et al., 2007) (Fig. 8).

The Cann Sand Member of the type area is 25 to 30 m thick and dated as $H$. varicosum Subzone (Bristow et al., 1995). In contrast, the slightly thinner Cann Sand of the Devizes district includes a significant thickness of $C$. auritus Subzone sediments (Fig. 8). The top of the Gault belongs to the varicosum Subzone in the Shaftesbury and Salisbury districts (Bristow et al., 1995), and probably the orbignyi or basal varicosum Subzone in the Devizes district.

The Shaftesbury Sandstone Member is a 10 to $25 \mathrm{~m}$ thick interval in its type area, and comprises coarse-grained, glauconitic silt to fine-grained sand and weakly calcitecemented sandstone, capped by hard, oyster-rich, calcite-cemented glauconitic sandstone, traditionally termed 'Ragstone' (Bristow et al., 1999). The bulk of the Shaftesbury Sandstone Member probably belongs to the $H$. varicosum Subzone, and with the underlying Cann Sand, represents a greatly expanded interval (locally up to 40 m thick) compared to the likely thickness of $H$. varicosum Subzone Upper Greensand in the Devizes district (less than $10 \mathrm{~m}$ ). The only part of the Upper Greensand in the Wincanton district thought to belong to the C. auritus Subzone is the 'Ragstone' (Bristow et al., 1999), and even this is a tentative biozonal assignment. If the 'Ragstone' does belong to the auritus Subzone, then this relatively thin unit (c. $3 \mathrm{~m}$ maximum thickness) appears to correlate with the upper part of the Cann Sand and the overlying Potterne Sandstone, with a combined thickness of more than 20 m (Fig. 8). Drummond (1970) regarded the 'Ragstone' as being equivalent to the Potterne Rock, at the top of the Potterne Member, but this is clearly too simplistic. 
The Boyne Hollow Chert Member is a glauconitic sandstone characterised by the development of horizons of chert and siliceous concretions, and locally beds of chert up to $0.6 \mathrm{~m}$ thick (Bristow et al., 1999). There are few if any cherts in the postPotterne Rock greensand succession (i.e. Easterton Sandstone) near Devizes, but the thickness of sediment $(c .20 \mathrm{~m})$ to the base of the Chalk Group is similar to the maximum thickness of the Boyne Hollow Chert in the Wincanton district. JukesBrowne (1905, p. 14) also appears to have considered that strata equivalent to the Easterton Sandstone (his Upper Selbornian) were coeval with the chert-bearing units further southwest, but lacking the development of chert.

\section{Depositional history}

Relatively little has been published about the depositional history of the Upper Greensand. Jukes-Browne (1892) first observed that the base of the formation is contemporaneous with the Gault, and there is a well established general concept of diachronous eastward advance of the Upper Greensand fed by sediment source areas in southwest Britain (Hancock \& Rawson, 1992). The base of the Upper Greensand is demonstrably younger in the Weald (late C. auritus Subzone at Selborne; Woods et al., 2001) compared to the Shaftesbury and Devizes districts. A key requirement in understanding the depositional history of the Devizes Upper Greensand succession is determining whether underlying structures were controlling the development of the succession, or whether distance from the basin margin and sediment source areas was the dominant influence; or perhaps a combination of the two. 
Synsedimentary structural influences have previously been used to explain lateral thickness changes in the Gault and Upper Greensand elsewhere in southern England (Owen, 1996). The biostratigraphical correlation of the Devizes and Shaftesbury Upper Greensand successions shows that there were strong lateral differences in the volume and style of Upper Greensand sedimentation (Fig. 8). Could this be evidence of local synsedimentary tectonics? The Devizes area is intersected by the major east west trending Vale of Pewsey Fault Zone (Fig. 9). Like the Mere Fault further south, the Pewsey Fault developed progressive normal (southward downthrow) displacement through much of the Mesozoic in response to regional extension (Chadwick et al., 1983). Although both faults have experienced Cainozoic reversal, the sense of the earlier Mesozoic displacement is revealed through the thicker pre-Aptian successions immediately south of these structures. However, this tectonic influence on deposition seems to have ceased by the Albian, which was a time characterised by the virtual absence of normal faulting and low rates of tectonically driven subsidence (Chadwick et al., 1983; Chadwick, 1985, 1986). The only significant exceptions to this were the faults bordering the northern Weald and the Purbeck - Isle of Wight Fault system (Chadwick, 1985). In the eastern Weald, this structural influence is demonstrated by substantial tectonically driven changes in the thickness of the C. auritus Subzone in the Gault and Upper Greensand (Owen, 1996). In the Devizes area, it is possible that the Pewsey Fault Zone had some subtle influence on local basin architecture resulting from greater compaction of the thicker pre-Albian sedimentary succession on the downthrow side of this structure. Given that the main Vale of Pewsey Fault lineament probably tracks just south of Devizes (Fig. 9), any compaction effects would have had greatest influence south of this structure, and may have acted to maintain accommodation space for Upper Greensand deposition. Whilst this could theoretically 
explain the relatively thick C. auritus Subzone sediments in this area, it does not easily explain why the underlying $H$. varicosum Subzone is relatively thin compared to areas to the southwest.

Alternatively, a strong case can be made for explaining the contrasting features of the $H$. varicosum and C. auritus Subzone deposits of the Devizes area in terms of basin palaeogeography and distance from sediment source areas. The similar thicknesses of Gault in the Shaftesbury and Devizes districts suggests that they shared a broadly common basin architecture, with no inherent structural reason for differences in sediment accumulation patterns, at least in the Mid and early Late Albian. Deposition of sand-rich facies (Cann Sand \& Shaftesbury Sandstone) was locally voluminous in the H. varicosum Subzone of the Shaftesbury district, but more limited in the Devizes district. This discrepancy might simply reflect closer proximity of the Shaftesbury area to a richer supply of arenaceous sediment. The condensed, oyster-rich facies of the 'Ragstone' (Fig. 8) in the Shaftesbury, Wincanton and Salisbury districts suggests that shallow water conditions became established south and southwest of the Devizes district in the C. auritus Subzone, at a time when substantially thicker, ammonitebearing (and probably deeper water) sediments were being deposited around Devizes. The Ragstone may therefore indicate the effective infilling of available accommodation space south and southwest of Devizes by the beginning of the $C$. auritus Subzone, forcing the locus of sedimentation to move basinward towards Devizes. Compaction of pre-Albian Mesozoic successions on the downthrow side of the Pewsey Fault Zone may have maintained greater accommodation for sediment in the Devizes area, but it seems more likely that it was lack of available space further south and west that focused sedimentation in this area rather than direct structural 
control. Boreholes at Selborne (Hopson et al., 2001; Woods et al., 2001) show that eastward thickening of the C. auritus Subzone, from Shaftesbury towards the western Weald, could be part of a regional trend.

The phosphatic sediments of the Potterne Sandstone probably relate to an erosional winnowing and subsequent transgression event that heralded a global sea level rise in the latest C. auritus Subzone and earliest S. dispar Zone (Haq et al., 1987; Hancock \& Rawson, 1992; Bristow et al., 1995; Owen, 1996). This rise in sea level created new accommodation space for S. dispar Zone age Upper Greensand deposition extending from the western basin margins to the central Weald Basin.

\section{Chert development in the Upper Greensand}

Chert is a characteristic feature of the highest (S. dispar Zone) part of the Upper Greensand across much of southwest England (Devon, Dorset, parts of Wiltshire \& the Isle of Wight); in central Dorset it is locally absent across a structural high (the 'Mid-Dorset Swell' of Drummond, 1970). Chert is less common in the Weald, but persists as local thin nodular and tabular horizons (Dines \& Edmunds, 1929, 1933;

Owen et al., 1996; Hopson et al., 2001). Chert-bearing Upper Greensand is largely absent in the Devizes district, although strata that are coeval with chert bearing successions in adjacent areas are present (i.e. Easterton Sandstone), and chert becomes re-established in the succession some $20 \mathrm{~km}$ east of Devizes (e.g. around Grafton and Burbage; Jukes-Browne, 1905). 
Previous work on chert development, including the Upper Greensand, has suggested a correlation with depositional environment, with chert being most abundant in subtidal marine deposits, at or below fair-weather wave base, and absent or rare in supratidal, intertidal and high energy settings (Maliva \& Siever, 1989). This might be explained by an environmental influence on the distribution of siliceous sponges, which are strongly implicated as the source of most of the chert-forming silica in the Upper Greensand (Maliva \& Siever, 1989). Where chert does begin to reappear in the succession east of Devizes, it is accompanied by the appearance of common sponge remains (Jukes-Browne \& Hill, 1900; Jukes-Browne, 1905).

Whilst we have not systematically investigated why there is an absence of chert in the Easterton Member, there is some sedimentological evidence (abundance of glauconite; historical records of conspicuous current bedding between Devizes and Pewsey and near Market Lavington and West Lavington - Jukes-Browne \& Hill, 1900; Jukes-Browne, 1905) and faunal evidence (paucity of macrofauna and bioturbation), that are consistent with low rates of sedimentation in a moderate to high energy environment. In chert-bearing Upper Greensand, glauconite and detrital quartz are usually less abundant, and bioclastic material more abundant, than in the Easterton Member (Maliva \& Siever, 1989). Palaeogeographic reconstructions for the latest Albian S. dispar Zone, following a global rise in sea level, show that the Devizes district was close to the eastern mouth of a narrow seaway that occupied the region of the Bristol Channel (Rawson \& Hancock, 1992, map K3; Fig. 9). We speculate that this palaeogeographic setting may have enhanced the activity of strong marine currents in the Devizes area at the time when the Easterton Sandstone was being deposited, and be linked to the absence of chert. 


\section{CONCLUSIONS}

The new three-fold member lithostratigraphy of the Upper Greensand in the Devizes district (Cann Sand, Potterne Sandstone and Easterton Sandstone) provides a much clearer way of subdividing and correlating the succession than either historical or recently introduced schemes for neighbouring areas (e.g. Shaftesbury, Wincanton districts). The new lithological subdivisions, allied with biostratigraphical data, show that there are important contrasts in the style and timing of sedimentation in the Devizes area compared to other areas of southwest England, and provide significant insights to the broader depositional development of the Upper Greensand across the Wessex Basin. Following a latest Albian (S. dispar Zone) rise in sea level, the Devizes area may have been in the path of strong marine currents funnelled through a narrow seaway in the region of the Bristol Channel. This could explain the distinctive lithological features of the youngest Upper Greensand (Easterton Sandstone), and account for the absence of chert development at this level.

\section{ACKNOWLEDGEMENTS}

The authors would like to thank the following BGS colleagues for their expertise and perseverance in drilling cored boreholes in the challenging ground conditions of the Upper Greensand: Steve Thorpe, David Minchin, Andreas Scheib, Hannah Cullen,

Chris Slater, Ricky Terrington and Nathan Williams. Thanks also to Steve Booth, for managing drilling operations, and to the landowners of the Devizes district who kindly allowed access during fieldwork and borehole drilling. We are also grateful to. 
S. G. Molyneux and N. J. P. Smith for early reviews of this manuscript, and S. R. A. Kelly for helpful comments following later reviews. National Grid coordinates are used with kind permission of the Ordnance Survey. This paper is published with the permission of the Executive Director of the BGS (NERC).

\section{A. APPENDIX: SUMMARY OF LITHOSTRATIGRAPHICAL UNITS}

\section{Cann Sand Member}

Type area: The member is well developed around the hamlet of Cann, south-east of Shaftesbury.

Principal reference section in type area: Church Farm No. 2 Borehole [ST 8555 2223], $1.96 \mathrm{~m}-5.21 \mathrm{~m}$ depth.

Principal reference sections in Devizes district: Furze Hill Farm [ST 98868 59993, ST 98857 59981, ST 98834 59950]; Coulston [ST 95339 53904]; Old Park Farm Borehole [ST 99476 60353]; Knights Leaze Farm Borehole [SU 03837 57419].

Lithology: Sand, fine-grained, glauconitic, micaceous, with rounded concretions and tabular horizons of hard, calcareous sandstone in the upper part of the member.

Thickness: $21 \mathrm{~m}$ (Devizes district).

Age: Late Albian. $H$. varicosum Subzone (type area); H. varicosum and C. auritus subzones (Devizes district).

Definition of base: Upward change from silty mudstone of the Gault to muddy siltstones and sandstones.

Definition of top: The upper limit of mica-rich sandstone.

Bibliographic reference: Bristow (1989). 
Potterne Sandstone Member (newly defined herein)

Type area: Near the village of Potterne, 2 km SSW of Devizes.

Principal Reference Section: Coxhill Lane, Potterne [SU 00125840 to

SU 0062 5842]

Lithology: Soft, grey and greenish-grey, poorly micaceous sandstone with conspicuous burrows and scattered phosphatic clasts. One or more beds of hard sandy limestone cap the member ('Potterne Rock').

Thickness: Up to $4 \mathrm{~m}$.

Age: C. auritus Subzone.

Definition of base: The upward change from conspicuously micaceous glauconitic sandstone of the Cann Sand, to poorly micaceous, glauconitic sandstone.

Definition of top: One or more closely spaced beds of hard, sandy limestone with phosphatic clasts ('Potterne Rock') mark the top of the member.

Easterton Sandstone Member (newly defined herein)

Type area: Limited exposures occur near the village of Easterton, $5.5 \mathrm{~km}$ SSE of Devizes.

Principal Reference Sections: Folly Wood [SU 0195 5683], near Easterton Sands; Rookery Farm Borehole [SU 04010 56742], near Urchfont.

Lithology: Strongly glauconitic sandstone with occasional beds of hard, calcareous sandstone or sandy limestone. Generally coarser-grained than Potterne Sandstone and poorly fossiliferous.

Thickness: $c .20 \mathrm{~m}$ (estimated from field evidence).

Age: S. dispar Zone (largely inferred). 
Lower boundary: Immediately above one or more beds of hard, sandy limestone ('Potterne Rock') at the top of the Potterne Sandstone Member.

Upper boundary: The base of the Chalk Group, marked by an irregular erosion surface overlain by the Glauconitic Marl Member. 


\section{REFERENCES}

Barrois, C. 1876. Recherches sur le Terrain Crétacé supérieur de l'Angleterre et de l'Irlande. Memoir Sociéte Géologique du Nord, 1, 234 pp.

Bristow, C. R. 1989. Geology of the East Stour - Shaftesbury district (Dorset). 1:10 000 sheets ST82SW and 82SE. British Geological Survey Technical Report WA/89/58.

Bristow, C. R., Barton, C. M., Freshney, E. C., Wood, C. J., Evans, D. J., Cox, B. M., Ivimey-Cook, H. \& Taylor, R. T. 1995. Geology of the country around Shaftesbury. Memoir of the British Geological Survey, (Sheet 313, England \& Wales).

Bristow, C. R., Barton, C. M., Westhead, R. K., Freshney, E. C., Cox, B. M., Woods, M. A. 1999. The Wincanton district - a concise account of the Geology. Memoir of the British Geological Survey (Sheet 297, England \& Wales).

Chadwick, R. A. 1985. 13. Cretaceous sedimentation and subsidence (Aptian to Albian). 57 - 58 in Atlas of onshore sedimentary basins in England and Wales.

Whittaker, A. (ed.). (Glasgow \& London: Blackie).

Chadwick, R. A. 1986. Extension tectonics in the Wessex Basin, southern England. Journal of the Geological Society, London, 143, 465-488.

Chadwick, R. A., Kenolty, N. \& Whittaker, A. 1983. Crustal structure beneath southern England from deep seismic reflection profiles. Journal of the Geological Society of London, 140, 893-911.

Dines, H. G. \& Edmunds, F. H. 1929. Geology of the country around Aldershot and Guildford. Memoir of the Geological Survey, England and Wales.

Dines, H. G. \& Edmunds, F. H. 1933. The geology of the country around Reigate and Dorking. Memoir of the Geological Survey, England and Wales. 
Drummond, P. V. O. 1970. The Mid-Dorset Swell. Evidence of Albian - Cenomanian Movements in Wessex. Proceedings of the Geologists' Association, 81, 679-713. Hancock, J. M. \& Rawson, P. F. 1992. Cretaceous. 131-139 in Atlas of Palaeogeography and Lithofacies, Cope, J. C. W., Ingham, J. K. \& Rawson, P. F. (editors) Memoir 13 (London: Geological Society.)

Haq, B. U., Hardenbol, J. \& Vail, P. R. 1987. Chronology of fluctuating sea levels since the Triassic. Science, 235, 1156-1167.

Hopson, P. M. 2005. A stratigraphical framework for the Upper Cretaceous Chalk of England and Scotland with statements on the Chalk of Northern Ireland and the UK Offshore Sector. British Geological Survey Research Report, RR/05/01.

Hopson, P. M., Farrant, A. R. \& Booth, K. A. 2001. Lithostratigraphy and regional correlation of the basal Chalk, Upper Greensand, Gault, and uppermost Folkestone formations (Mid-Cretaceous) from cored boreholes near Selborne, Hampshire. Proceedings of the Geologists’' Association, 112, 193-210.

Hopson, P. M., Farrant, A. R., Newell, A. J., Marks, R. J., Booth, K. A., Bateson, L. B., Woods, M. A., Wilkinson, I. P., Brayson, J. \& Evans, D. J. 2007. Geology of the Salisbury district - a brief explanation of the geological map. Sheet Explanation of the British Geological Survey, 1:50 000 Sheet 298 Salisbury (England \& Wales).

Hopson, P. M., Wilkinson, I. P. \& Woods, M. A. 2008. The Lower Cretaceous rocks of England: An overview of the terminology utilised within the British Geological Survey. A stratigraphical framework for the Lower Cretaceous rocks of England. British Geological Survey Research Report RR/08/03.

Jukes-Browne, A. J. 1892. The geology of Devizes, with remarks on the grouping of Cretaceous deposits. Proceedings of the Geologists’ Association, 12, 254-266. 
Jukes-Browne, A. J. 1905. The geology of the country south and east of Devizes. Memoir of the Geological Survey, England \& Wales.

Jukes-Browne, A. J. \& Hill, W. 1900. The Cretaceous rocks of Britain. Vol. 1 - The

Gault and Upper Greensand of England. Memoir of the Geological Survey of the United Kingdom.

Kelly, S. R. A. 1971. A new section in the Upper Greensand, near Edington, Wiltshire. Proceedings of the Geologists’ Association, 82, 445-448.

Maliva, R. \& Siever, R. 1989. Chertification histories of some Late Mesozoic and Middle Palaeozoic platform carbonates. Sedimentology, 36, 907-926.

Morter, A. A. \& Wood, C. J. 1983. The biostratigraphy of Upper Albian - Lower Cenomanian Aucellina in Europe. Zitteliana, 10, 515-529.

Owen, H. G. 1975. The stratigraphy of the Gault and Upper Greensand of the Weald. Proceedings of the Geologists’ Association, 86, 475-498.

Owen, H. G. 1984. The Albian Stage: European Province Chronology and Ammonite Zonation. Cretaceous Research, 5, 329-344.

Owen, H. G. 1996. The Upper Gault and Upper Greensand of the M23/M25/M26 motorway system and adjacent sections, Surrey and Kent. Proceedings of the Geologists’ Association, 107, 167-188.

Owen, H. G. \& Mutterlose, J. 2006. Late Albian ammonites from offshore Suriname: implications for biostratigraphy and palaeobiogeography. Cretaceous Research, 27, $717-727$.

Owen, H. G., Shephard-Thorn, E. R. \& Sumbler, M. G. 1996. 6. Lower Cretaceous. 61-76 in British regional geology: London and the Thames Valley (4 ${ }^{\text {th }}$ edition). Sumbler, M. G. (compiler). (London: HMSO for the British Geological Survey). 
Price, R. J. 1977. The stratigraphical zonation of the Albian sediments of north-west Europe, as based on foraminifera. Proceedings of the Geologists' Association, 88, 6591.

Spath, L. F.1923 - 1943. A monograph of the ammonoidea of the Gault. Monograph of the Palaeontographical Society, 787 pp.

Woods, M. A., Wilkinson, I. P., Dunn, J. \& Riding, J. B. 2001. The biostratigraphy of the Gault and Upper Greensand formations (Middle and Upper Albian) in the BGS Selborne boreholes, Hampshire. Proceedings of the Geologists’ Association, 112, 211-222. 
Figure 1. Location of key exposures and new BGS cored boreholes in the Upper Greensand Formation of the Devizes district. Based upon OS material (C) Crown Copyright. All rights reserved. Licence 100017897/ 2009.

Figure 2. The stratigraphical classification of the Upper Greensand of the Devizes district (not to scale).

Figure 3. Established and newly revised ammonite biozonal schemes for the Late Albian.

Figure 4. Composite stratigraphy for the Upper Greensand Formation of the Devizes district based on information from outcrops and cored boreholes.

Figure 5. The lithostratigraphical correlation of key outcrops of Upper Greensand in the Devizes district. Locality numbers refer to Figure 1.

Figure 6. Lithostratigraphy and key fauna of new BGS cored boreholes drilled to investigate the stratigraphy of the Upper Greensand of the Devizes district.

Figure 7. Outcrop features of the Upper Greensand seen near Devizes. (a) Ironstained weathered outcrop of upper part of Cann Sand Member with large rounded concretions (Cr) in lower part; height of face c. 5 m; near Devizes Castle [ST 99949 61536]. (b) The Potterne Rock forming a conspicuous overhang at the top of greenish-grey weathering Potterne Sandstone Member; Friar’s Lane, Urchfont [SU 0426 5717]. (c) Close-up of the Potterne Rock showing bioturbation and black 
phosphatic clast; Friar's Lane, Urchfont [SU 0426 5717]; field of view is c. $120 \mathrm{~mm}$.

(d) Richly glauconitic facies of the Easterton Sandstone Member; hammer c. 300 mm; temporary excavation near Etchilhampton [SU 05818 60407].

Figure 8. Biozonal correlation of the Upper Greensand of the Shaftesbury, Wincanton and Salisbury districts with the Devizes district. Left hand column uses Shaftesbury succession thicknesses based on maximum member thicknesses (unaffected by local thinning caused by the Mid-Dorset Swell) recorded by Bristow et al. (1995).

Figure 9. Palaeogeography of southern Britain in the latest Albian (S. dispar Zone), with present-day Gault and Upper Greensand outcrop and Vale of Pewsey Fault and Mere Fault superimposed. Based on Rawson \& Hancock (1992, map K3). 

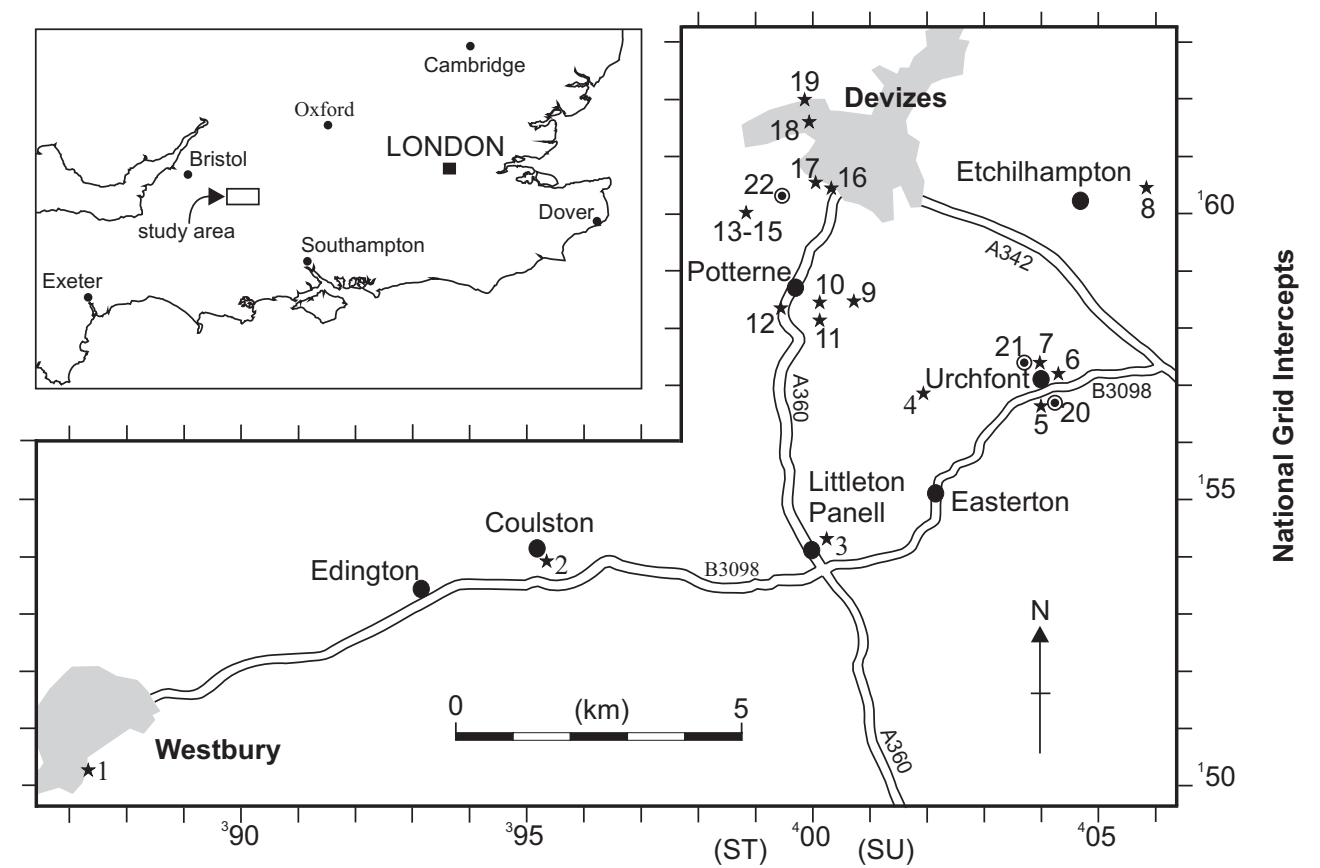

National Grid Intercepts

Key:

Outcrop localities $(\star)$

1: Westbury [ST 87368 50266]

2: Coulston [ST 9535553947 to 95376 53796]

3: Littleton Panell [SU 0025 5430]

4: Folly Wood, Easterton Sands [SU 0195 5683]

5: Footpath to Urchfont Hill [SU 03982 56592]

6: Friar Lane, Urchfont [SU 0426 5717]

7: Peppercombe Lane, Urchfont [SU 0395 5738]

8: Etchilhampton (temporary section)

[SU 05818 60407]

9: Bridleway near Stroud Hill Farm [SU 0071958423 to SU 0068158453 ]

10: Coxhill Lane, Potterne [SU 00125840 to SU 0062 5842]

11: Potterne [SU 00110 58096]

12: Potterne (old quarry) [ST 9947558308 ]

\author{
[ Near Furze Hill Farm [ST 98868 59993] \\ Near Furze Hill Farm [ST 98857 59981] \\ [ Near Furze Hill Farm [ST 98834 59950] \\ 16: Devizes, adjacent to A360 [SU 0036060400 to \\ SU 00240 60060] \\ 17: Devizes, Hartmoor Road [SU 00056048 to \\ ST 9993 6032] \\ 18: Devizes [ST 9994961536 ] \\ 19: Devizes [ST 9986061897 ] \\ Cored boreholes ( $(0)$ \\ 20: Rookery Farm BH01 [SU 04015 56632] \\ BH01B [04010 56742 \\ 21: Knights Leaze Farm [SU 03837 57419] \\ 22: Old Park Farm [ST 99476 60353]
}


Jukes-Browne (1892)

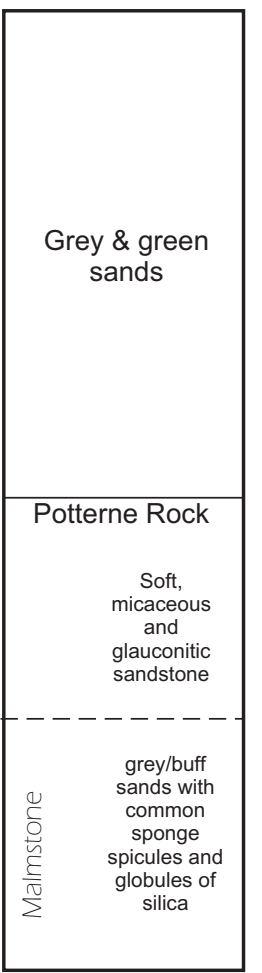

Jukes-Browne \& Hill (1900)

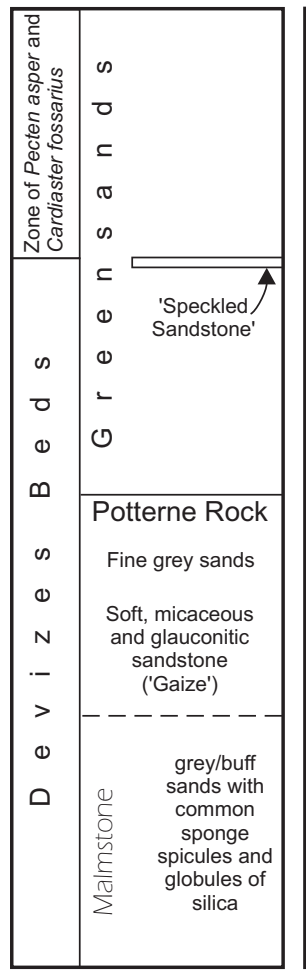

Jukes-Browne (1905)

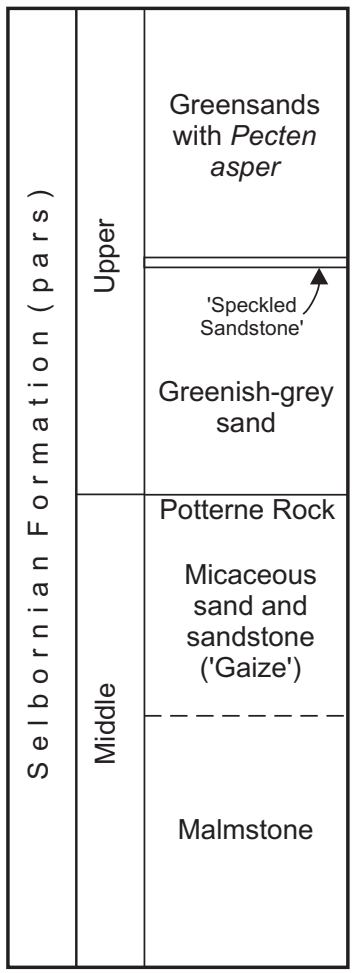

This Work

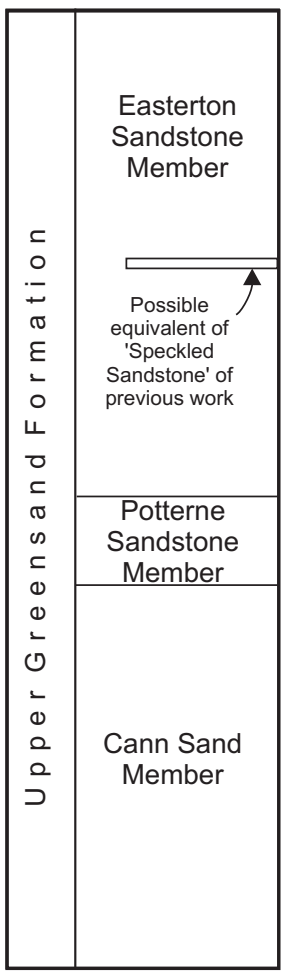

(Figure 2) 


\begin{tabular}{|c|}
\hline $\begin{array}{c}\text { Established ammonite biozonation } \\
\text { for the Late Albian } \\
\text { (e.g. Owen, 1975, Owen, 1984) }\end{array}$ \\
\hline
\end{tabular}

Revised ammonite biozonation for the
Late Albian
(e.g. Owen \& Mutterlose, 2006)

\begin{tabular}{|c|c|c|c|}
\hline Zone & Subzone & Zone & Subzone \\
\hline \multirow{3}{*}{$\begin{array}{l}\text { Stoliczkaia } \\
\text { dispar }\end{array}$} & (un-named) & \multirow{3}{*}{$\begin{array}{l}\text { Stoliczkaia } \\
\text { dispar }\end{array}$} & $\begin{array}{l}\text { Arrhaphoceras } \\
\text { (Praeschloenbachia) } \\
\text { briacensis }\end{array}$ \\
\hline & $\begin{array}{l}\text { Mortoniceras } \\
\text { (Durnovarites) perinflatum }\end{array}$ & & $\begin{array}{l}\text { Mortoniceras } \\
\text { (Durnovarites) perinflatum }\end{array}$ \\
\hline & $\begin{array}{l}\text { Mortoniceras }(M .) \\
\text { rostratum }\end{array}$ & & $\begin{array}{l}\text { Mortoniceras } \\
\text { (Mortoniceras) rostratum }\end{array}$ \\
\hline \multirow{5}{*}{$\begin{array}{l}\text { Mortoniceras (M.) } \\
\text { inflatum }\end{array}$} & Callihoplites auritus & $\begin{array}{l}\text { Mortoniceras (M.) } \\
\text { inflatum }\end{array}$ & \\
\hline & \multirow{2}{*}{ Hysteroceras varicosum } & \multirow{3}{*}{$\begin{array}{l}\text { Hysteroceras } \\
\text { varicosum }\end{array}$} & Hysteroceras choffati \\
\hline & & & Hysteroceras binum \\
\hline & Hysteroceras orbignyi & & Hysteroceras orbignyi \\
\hline & Dipoloceras cristatum & Dipoloceras cristatum & \\
\hline
\end{tabular}

(Figure 3) 


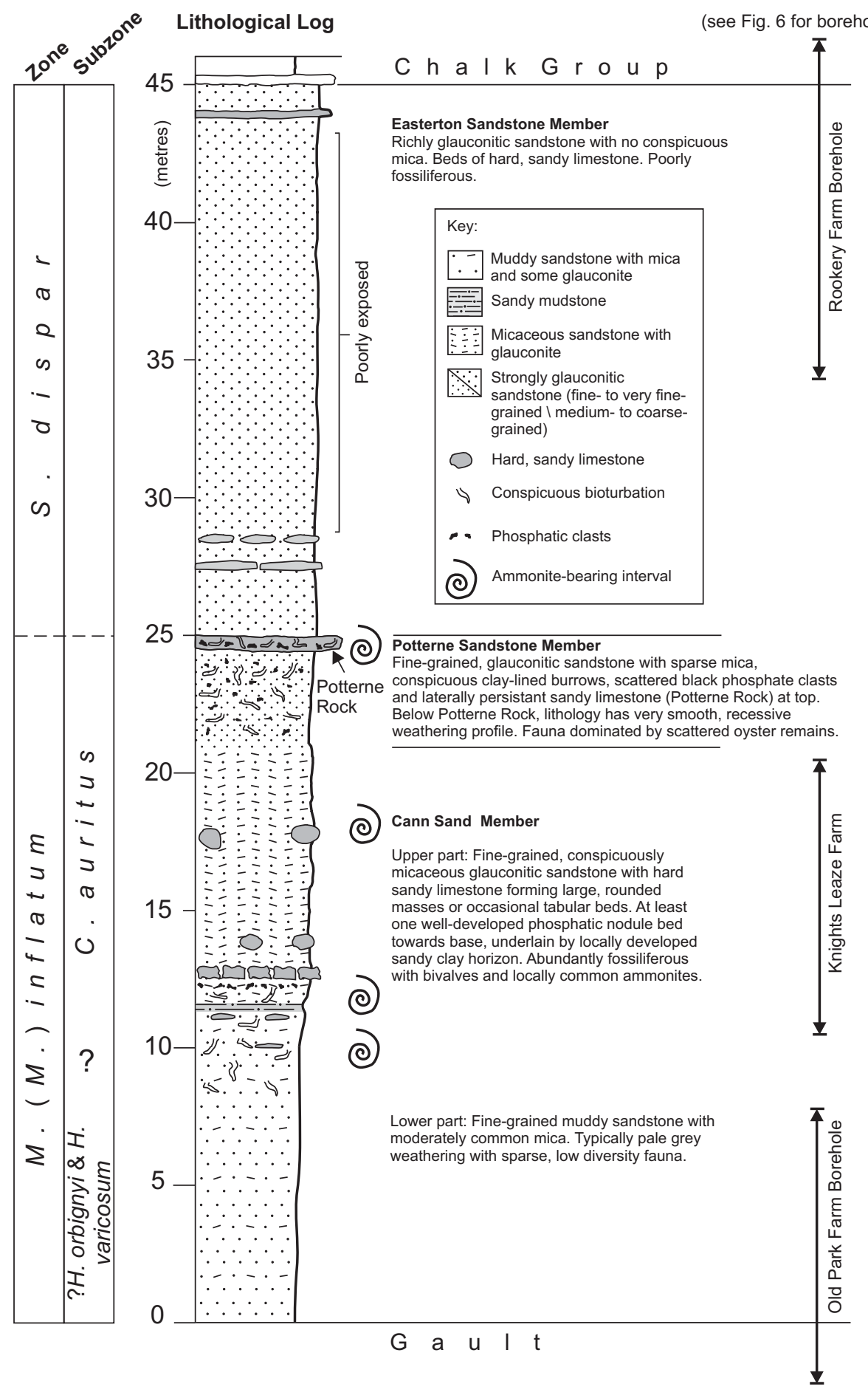

(Figure 4) 


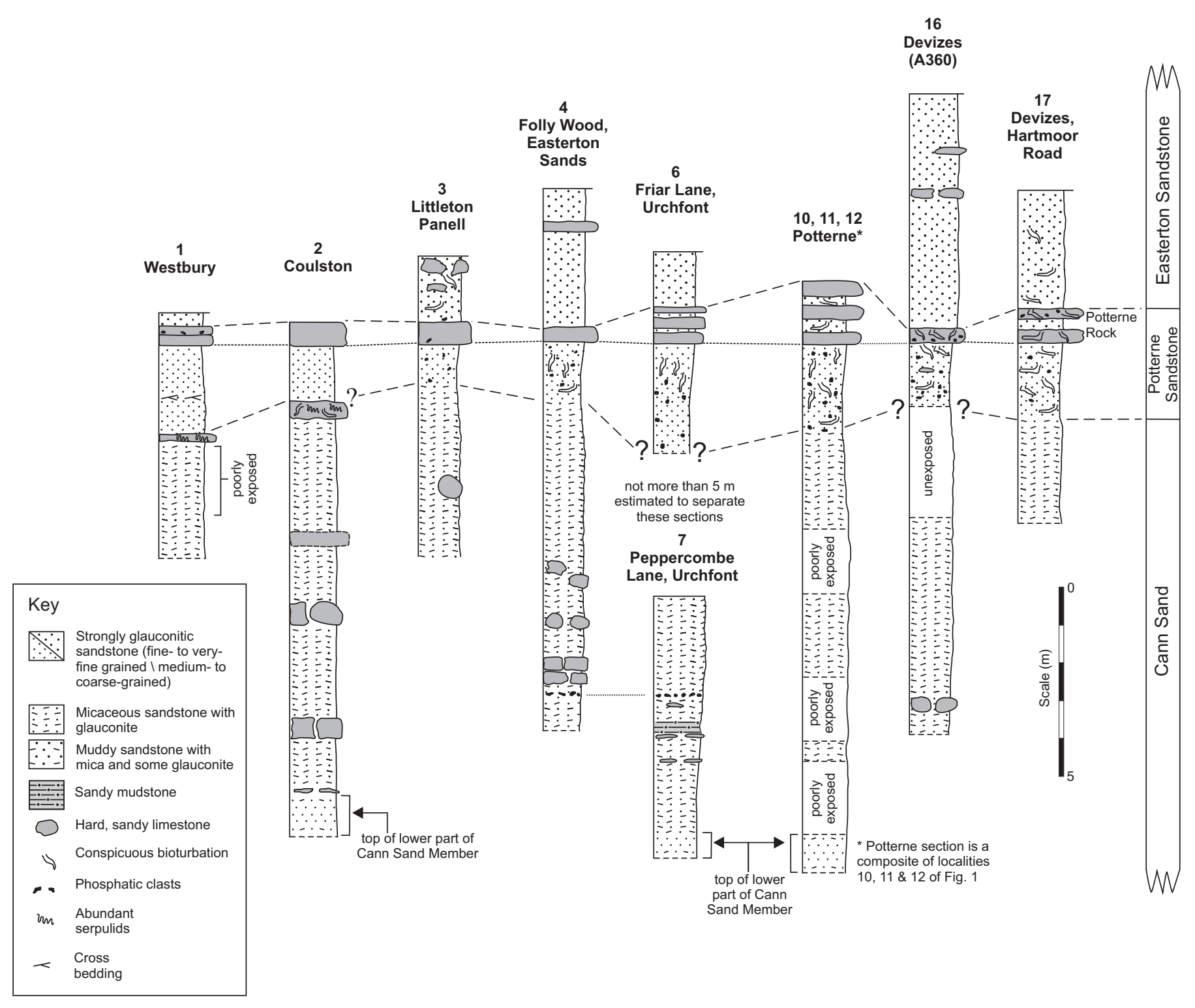

(Figure 5) 


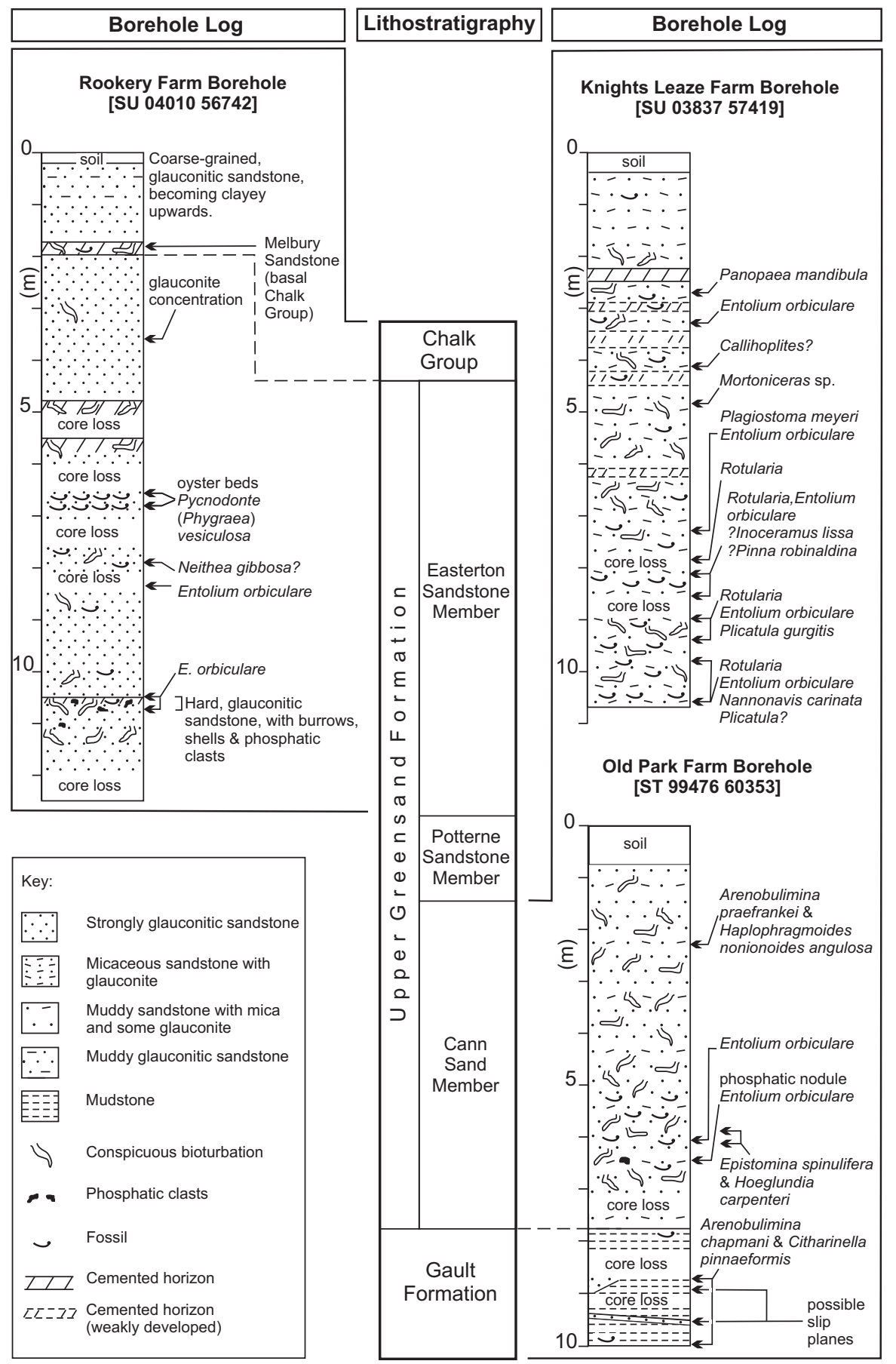



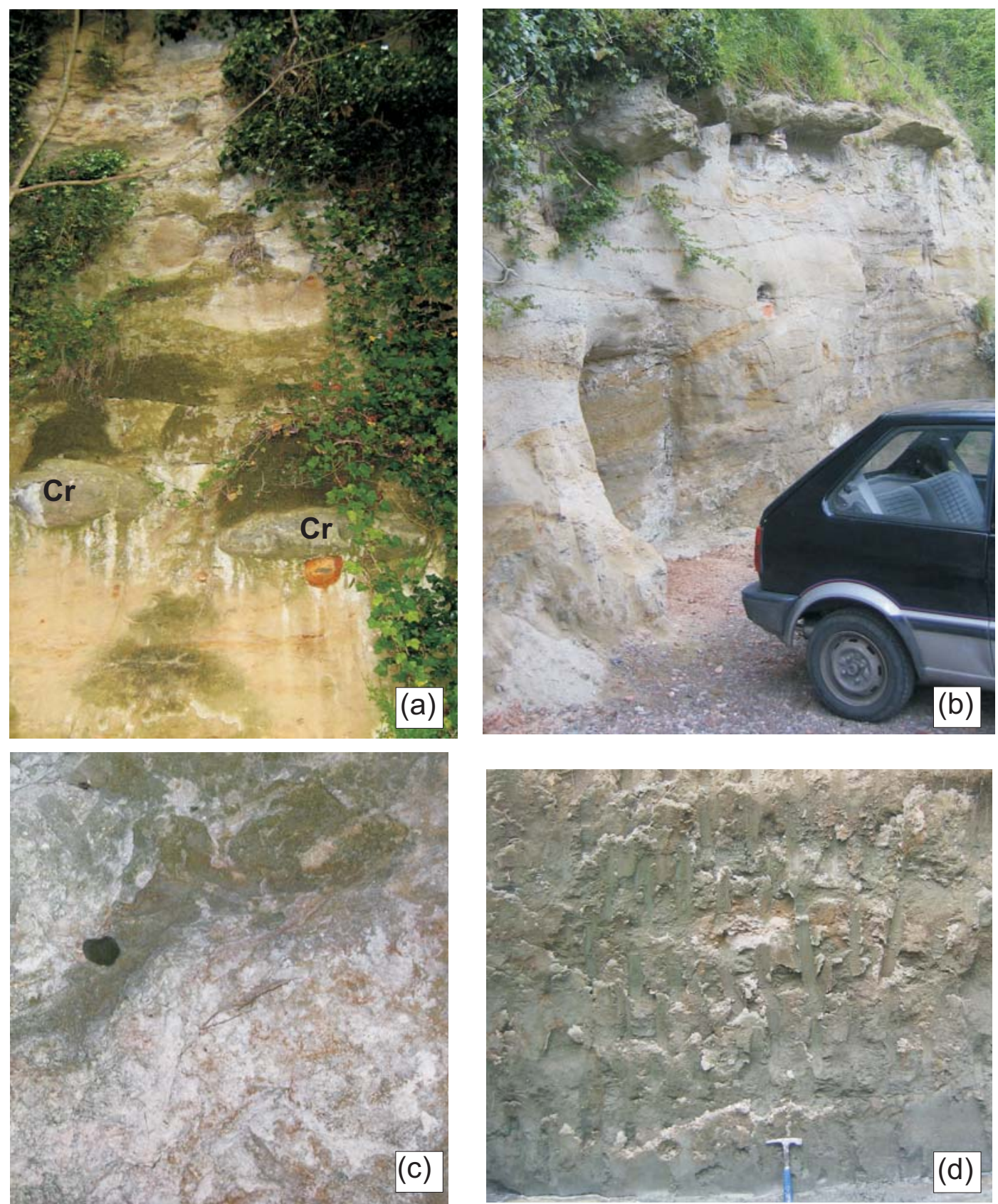

(Figure 7) 


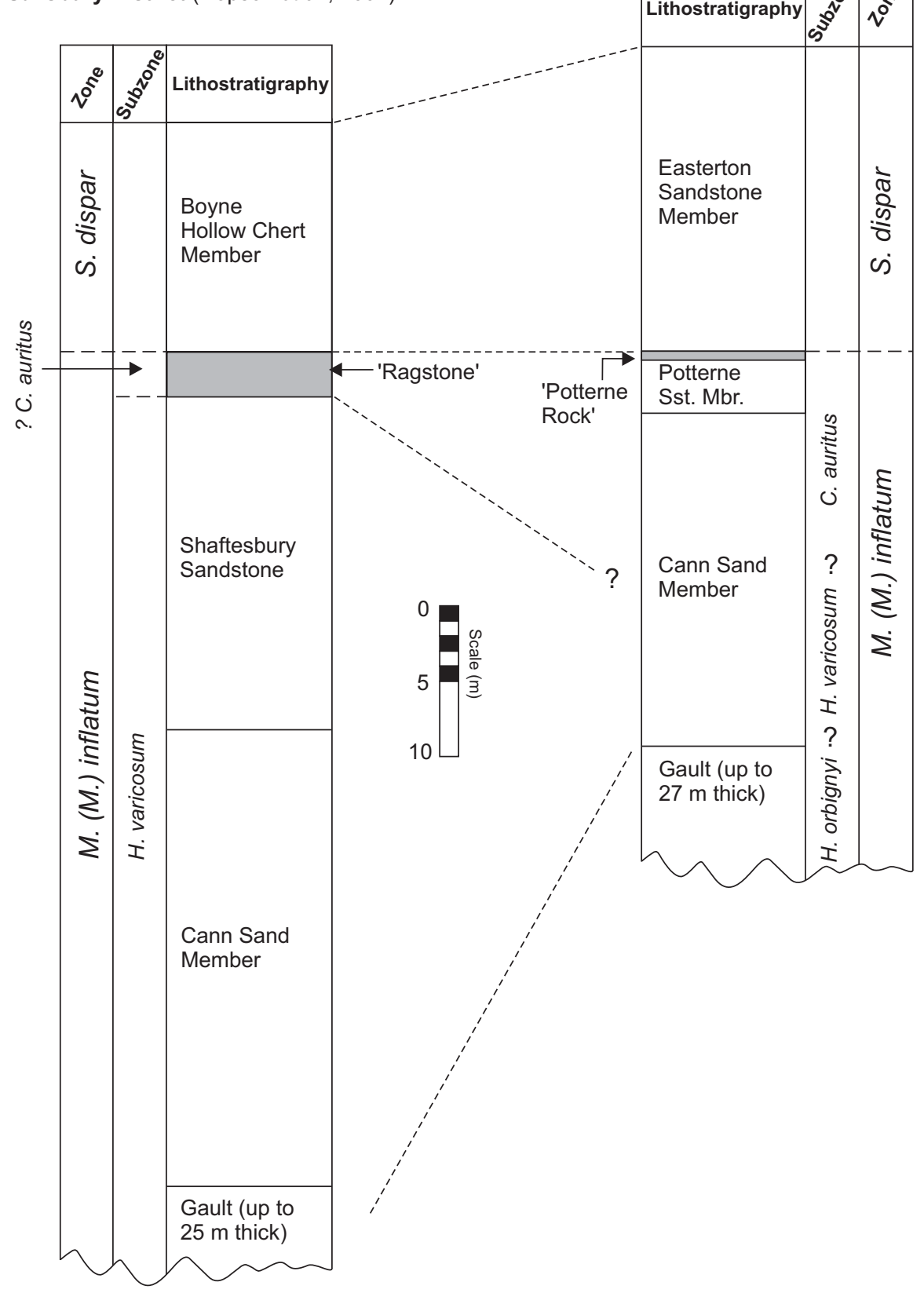

(Figure 8) 